\title{
Study on the Impact of Cutting Tool Wear on Machine Tool Energy Consumption
}

\author{
Andrzej Roszkowski ${ }^{*}$, Paweł Piórkowski', Wacław Skoczyński ${ }^{1}$, \\ Wojciech Borkowski', Tomasz Jankowski ${ }^{1}$ \\ 1 Wroclaw University of Science and Technology, ul. Wybrzeże Wyspiańskiego 27, 50-370 Wrocław, Poland \\ * Corresponding author's e-mail: andrzej.roszkowski@pwr.edu.pl
}

\begin{abstract}
The paper describes the problem of tool wear in machining processes. The importance of determining and analysing the demand of machining centres for electricity was emphasised and the potential relationship between tool wear and machine energy consumption was indicated. The paper presents the results of the measurements of cutting tool wear on the energy consumption of a machining centre based on the analysis of an actual technological process. The paper presents a method of obtaining and processing large amounts of data. The changes in the form of power consumption by the machine tool depending on the tool operation time and the machining cycle being implemented were shown. The researchers proposed the possibility of using the recorded data to develop an algorithm for automatic diagnosis of catastrophic tool wear. The usefulness of the collected and analysed data in the context of developing a method for determining the machine electricity demand was indicated.
\end{abstract}

Keywords: energy consumption, cutting tool wear.

\section{INTRODUCTION}

The growing demand for electricity in both the global and domestic economy forces consumers to reduce the energy consumption. One of the major sources that are responsible for the energy consumption is the electromechanical industry, including the machining industry [6]. Within this industry, many factors that determine the value of electricity consumption can be identified. In machining, machine centres play an important role in this respect. Their energy demand depends on the design features, the machining process, energy consumption of auxiliary devices, etc. [9]. Within these categories, minor factors, including the degree of the cutting tool wear, can also be distinguished.

The significance of the problem of energy demand can be demonstrated by numerous directives issued by the European Union bodies, as well as support from various global institutions for the initiatives related to reducing the carbon dioxide emissions into the atmosphere.
In Poland, in many fields of science, steps have been taken to examine the relationship between the energy consumption and the factors affecting it. In recent years, the publications that deal with this subject have appeared in the machine tool industry. The issues raised related to the energy consumption of machining processes relate to both planning of machining processes [10], determination of appropriate machining strategies [5], as well as analysis of new machining methods [2]. In this article, the impact of tool wear on the energy consumption of machining processes was analysed.

Tool wear is a natural process that occurs during machining. Depending on the cutting parameters adopted, the type of bit or material being cut, the rate of wear varies. After some time, the tool becomes worn to such an extent that it is not suitable for further machining. Tool wear leads to an increase in the forces resulting from the cutting resistance [13]; additionally, it affects the dimensional and shape accuracy of workpieces as well as surface roughness [14]. 
The main causes of tool wear include [3]:

- Adhesive wear,

- Mechanical wear,

- Abrasive wear,

- Wear due to heat,

- Wear due to oxidation,

- Diffusion wear,

- High temperature plastic deformation.

Each of these causes can occur with different intensity during the machining process; therefore, advanced mathematical tools are used to analyse and measure tool wear. One such method is the use of neural networks to determine the degree of tool wear [4]. The possibility of equipping machine tools with numerous sensors [8] means that during the attempts to monitor tool wear, other physical quantities that are associated with the gradual wear of the cutting tool can also be measured and analysed. There are, for example, specialist measuring sensors created for this purpose [1]. Direct and indirect methods are used to test the tool wear. The direct methods include the optical, induction and pneumatic techniques, whereas the indirect methods include measuring cutting force, noise emissions, vibrations and cutting temperature. There is also a solution that allows diagnosing catastrophic wear of the cutting tools using the analysis of engine power signal
[12]. The purpose of this paper was to analyse the impact of cutting tool wear on the machine's energy consumption and to evaluate the usefulness of the machine power consumption monitoring for the possibility of planning bit replacement.

\section{TEST METHODOLOGY}

The analysis used a Sonel PQM-701 power quality analyser, which can record the network parameters in real time. Hence, the active and reactive power values can be recorded with the assumed frequency. The power quality analyser was connected to the VF-7/50 vertical machining centre with a maximum rotational speed of 7500 rpm, according to the diagram [Fig. 1] included in the analyser's manual.

In the analysed period of work, the vertical machining centre carried out the machining processes of only one type of workpiece [Fig. 2]. The analyser was connected for a period of 12 days, which included 5 working days, 2 non-working days and another 5 working days. The manufacturing plant worked in one shift, so during the measurement, the signal of about 290 hours was recorded, and only part of the data concerned the machining tasks performed on the analysed

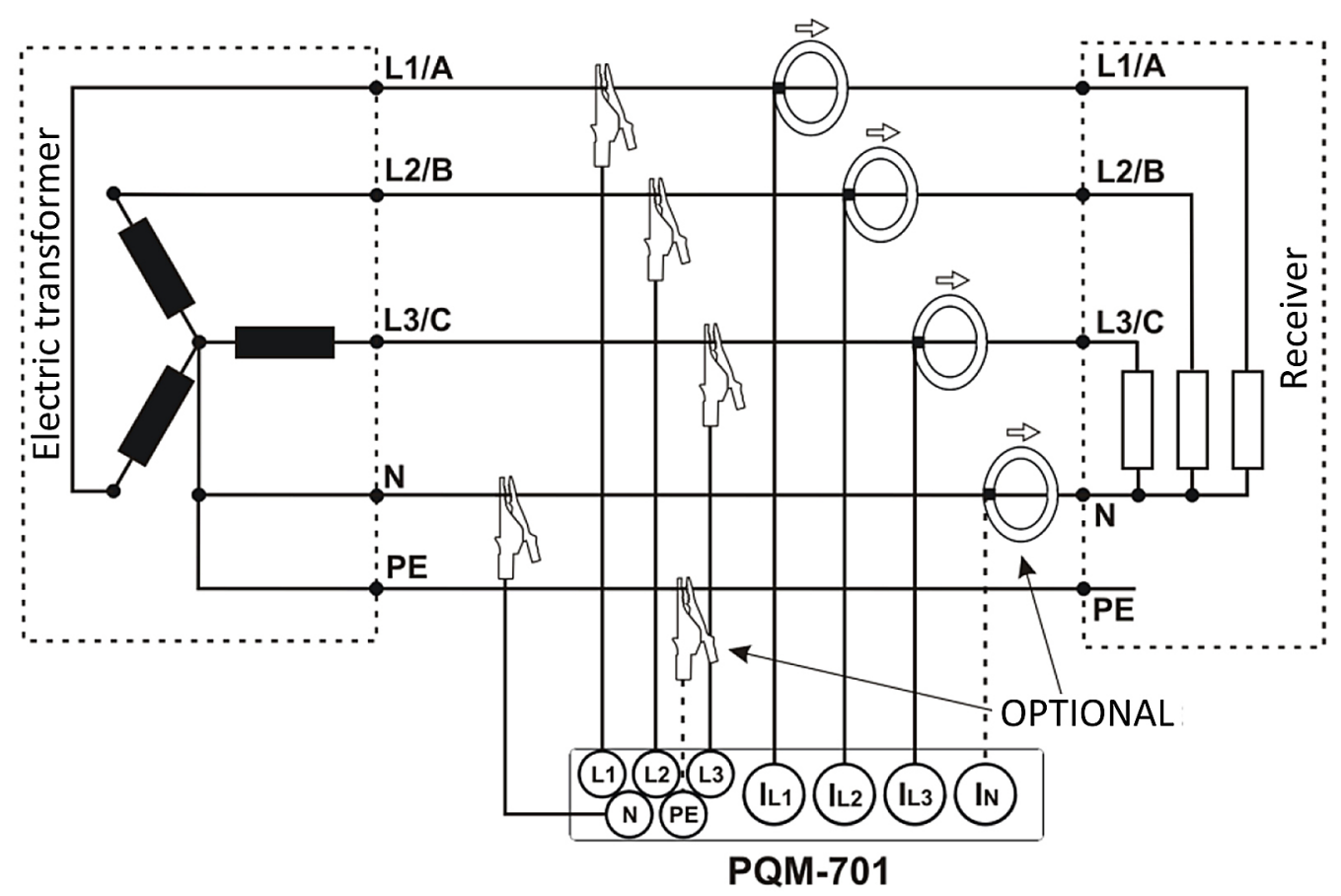

Fig. 1. Diagram for connecting the Sonel PQM-701 power quality analyser to machine tool wires [7] 


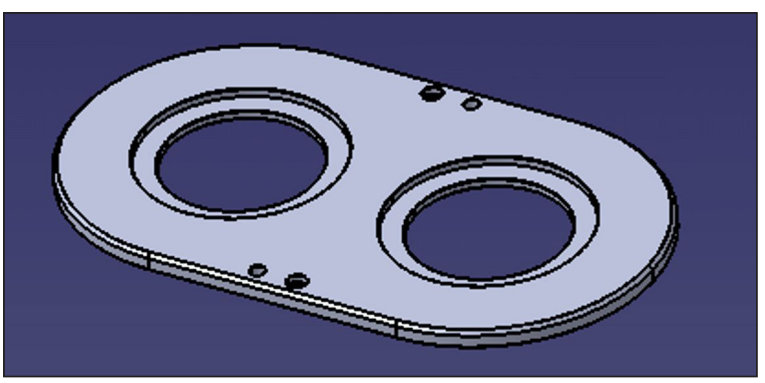

Fig. 2. Numerical model of the workpiece after all machining operations have been completed

workpiece. It is worth noting that during one shift, machine start-up, tool change or cleaning of the machine working space were also carried out. Therefore, the actual duration of the machining processes, along with the signal, which included the rapid and working movements of the tool, lasted about 20 hours, i.e. less than $10 \%$ of the length of the recorded signal.

During the machining of the analysed workpiece, 11 different tools were used [Table 1], among which there were 5 milling bits with different diameters, 2 drills with different diameters, a countersink, 2 chamfer bits with different diameters and a forming tap. The total volume of the chip when machining one workpiece was about $100 \mathrm{~cm} 3$, and the duration of one machining sequence was about 15 minutes.

Due to the fact that the data acquisition concerned not only the implementation of machining sequences, but also downtime, it was necessary to properly prepare and process the measurement data so that the information on the relationship between the tool working time and the energy consumption of the cutting process could be obtained. The diagram of the procedure is presented in Fig. 3.

First, the data from the power quality analyser were copied to a MATLAB script. The script allows for automatically removing the data from the signal that do not apply to the cutting process. This is followed by the process of intelligent separation from the entire record of 78 machine cycles, which are divided into individual machining operations. The data prepared in this way can be subjected to a statistical analysis, which allows calculating the value of instantaneous power and

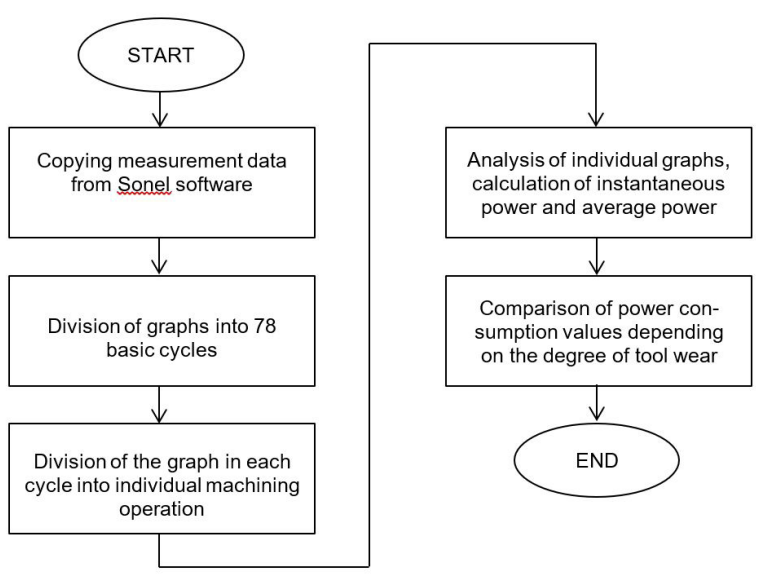

Fig. 3. Diagram of the procedure used to obtain information from measurement data on the relationship between the degree of tool wear and power consumption

Table 1. Cutting tools and parameters used in the process of machining the workpiece.

\begin{tabular}{|c|c|c|c|c|c|c|}
\hline Tool number & Tool name & $\mathbf{n}[\mathrm{rpm}]$ & $\mathbf{v}_{\mathrm{c}}[\mathrm{m} / \mathrm{min}]$ & $\mathbf{f}[\mathrm{mm} / \mathrm{rev}]$ & $\mathbf{z}$ & $\begin{array}{c}\text { Chip volume/ } \\
\text { cycle }\left[\mathrm{mm}^{3}\right]\end{array}$ \\
\hline 1 & Milling head $\Phi 200$ & 320 & 201 & 1.2 & 12 & 57963 \\
\hline 2 & Milling head $\Phi 63$ & 1153 & 228 & 1.07 & 9 & 5952 \\
\hline 3 & Milling head $\Phi 40$ & 1273 & 160 & 0.72 & 6 & 29444 \\
\hline 4 & Milling head $\Phi 25$ & 2037 & 160 & 0.3 & 2 & 2230 \\
\hline 5 & Milling head $\Phi 63$ & 1200 & 249 & 1.5 & 5 & 1473 \\
\hline 6 & VHM drill $\Phi 7.5$ & 2122 & 50 & 0.12 & - & 581 \\
\hline 7 & VHM drill $\Phi 7.5$ & 2122 & 60 & 0.12 & - & 1017 \\
\hline 8 & Countersink $\Phi 20.5$ & 388 & 25 & 0.3 & 3 & 808 \\
\hline 9 & Chamfer bit 90 $\Phi 10$ & 5000 & - & 0.24 & 6 & 20 \\
\hline 10 & Chamfer bit $\Phi 22.5$ & 4000 & 335 & 0.42 & 3 & 79 \\
\hline 11 & Forming tap M8 & 716 & 18 & 1.25 & - & - \\
\hline
\end{tabular}


average power for each machining operation, in each of the machine work cycles. During the energy consumption measurements, the machine tool operator wrote down the date and time during which he changed the cutting bits in each tool. Owing to the fact that the SONEL analyser assigns an accurate measurement time to each of the measured values, it was possible to compare the value of power consumption before and after the bit replacement and generate graphs of power consumption for individual tools.

\section{ANALYSIS OF TEST RESULTS}

First, the recorded instantaneous power consumption graphs were compared with a frequency of 5 samples per second for individual machining operations. It was observed that slightly different instantaneous power values were obtained for different machining cycle numbers, while the shape of the graph was the same each time. The graph shown below (Fig. 4) contains the graphs of all 78 machining cycles for the first machining operation performed with the $\varphi 200$ bit R220.48-8200-09-12 from SecoTools. It can be seen that during the operation, the tool starts and ends the cutting process four times, as evidenced by the lowest power consumption on the graph. Between the 1st and 2nd pass, and the 3rd and 4th pass, the tool moves quickly for a short time, while between the 2nd and 3rd pass, there is a break in the operation, resulting from the need to clean the working area. The duration of the first machining operation, including cleaning the working area, until the tool change, takes about 280 seconds. It can also be observed - especially during the 2nd and 4th entry of the cutting tool into the material - that the energy needed to perform the machining increases to a certain point, then drops sharply, and subsequently increases again. The moment of this decrease occurred between the 25th and 26th machining cycle.

After comparing the power consumption graphs from the 25th and 26th machining cycles with each other, it turned out that there were significant differences in the power consumption of the machine tool during cutting with a worn tool and a new tool (Fig. 5).

The graph below shows that depending on when the measurement was recorded, the instantaneous power consumed by the machine tool was greater by $5 \%$ to $60 \%$, depending on whether the machining operation was carried out with a new or worn tool. It is worth mentioning that these differences result directly from the machining process, since the sampling frequency of 5 samples per second applies only to the frequency of saving the measurement by the analyser. The analyser itself measures with a sampling frequency of about $12.8 \mathrm{kHz}$, and gives the measured power 5 times per second - every $200 \mathrm{~ms}$. This indicates that the tool condition resulting from its wear can have a different effect on the increase of the power consumption value, which means that the use of instantaneous power to monitor the tool condition can be problematic. Average power could definitely be a more useful parameter for

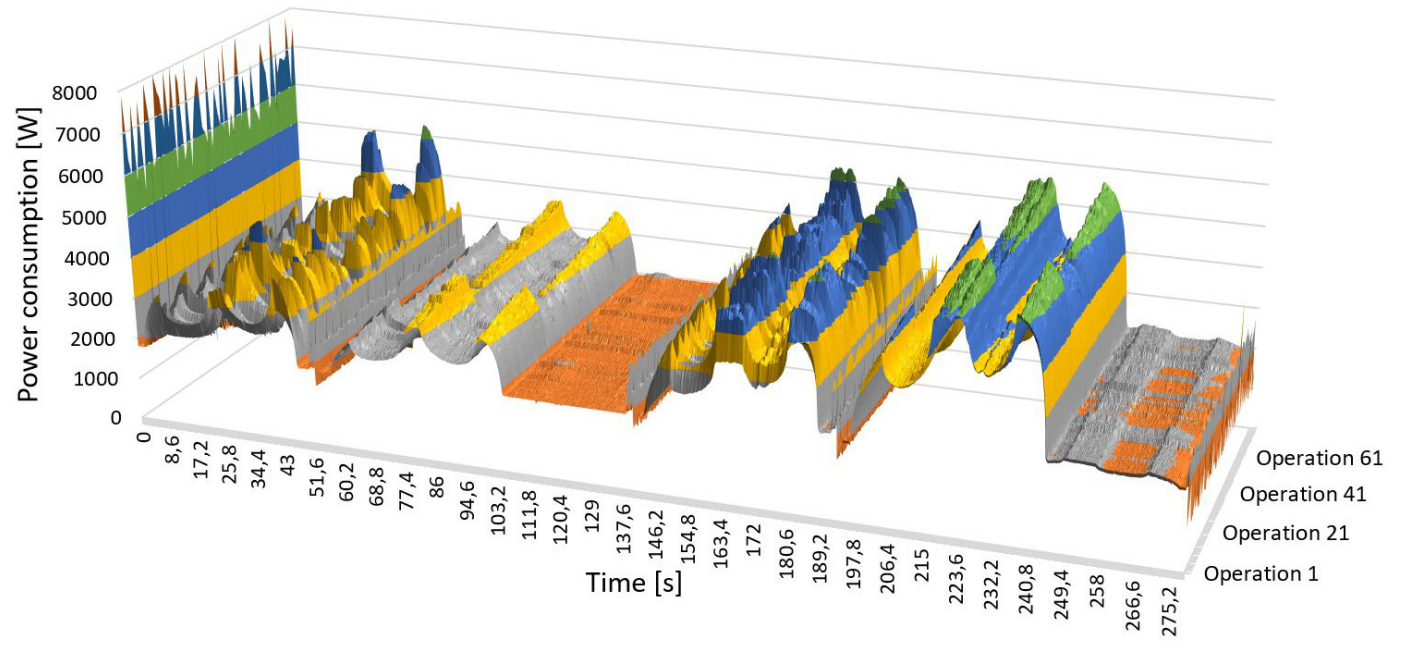

Fig. 4. Comparison of power consumption graphs for full machining cycles of 78 workpieces for the $\Phi 200$ bit R220.48-8200-09-12 from Seco Tools 


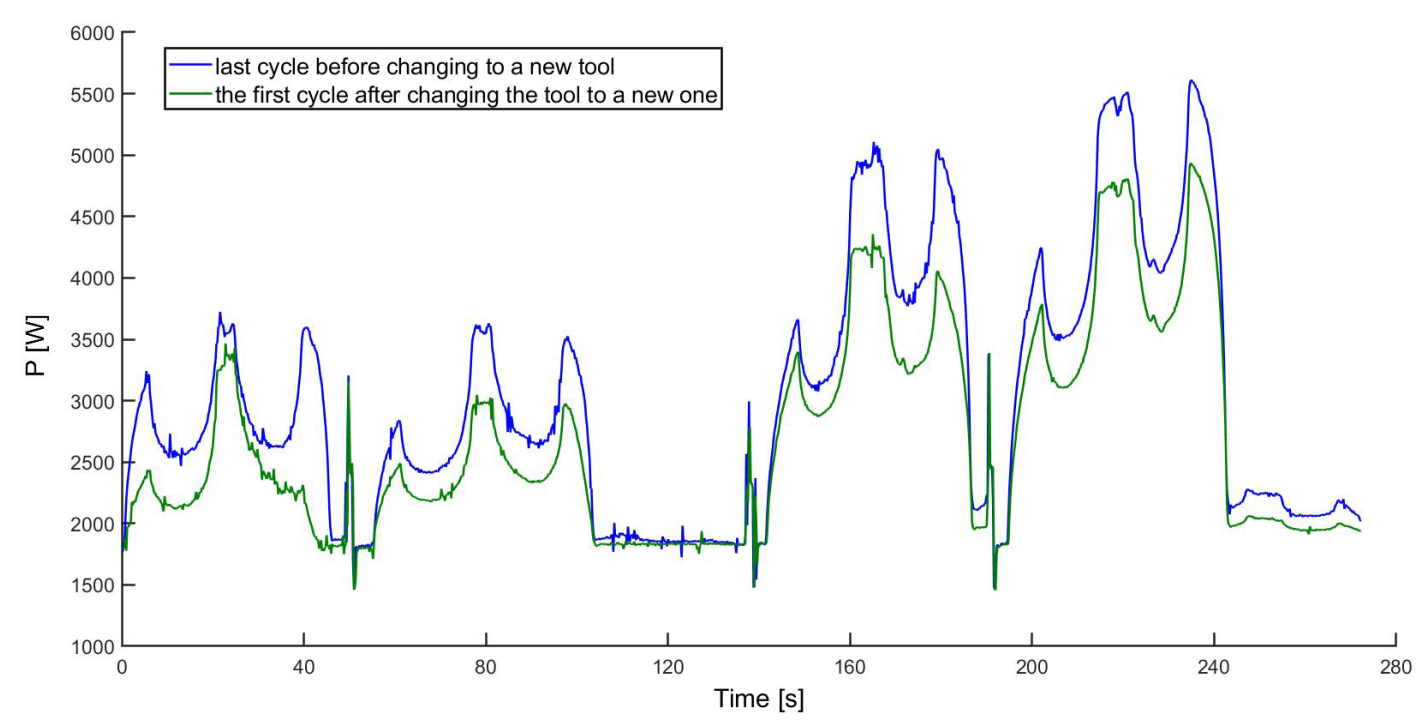

Fig. 5. Graph of momentary power as a function of time for two consecutive cycles before and after a tool change, for the $\Phi 200$ bit R220.48-8200-09-12 from Seco Tools

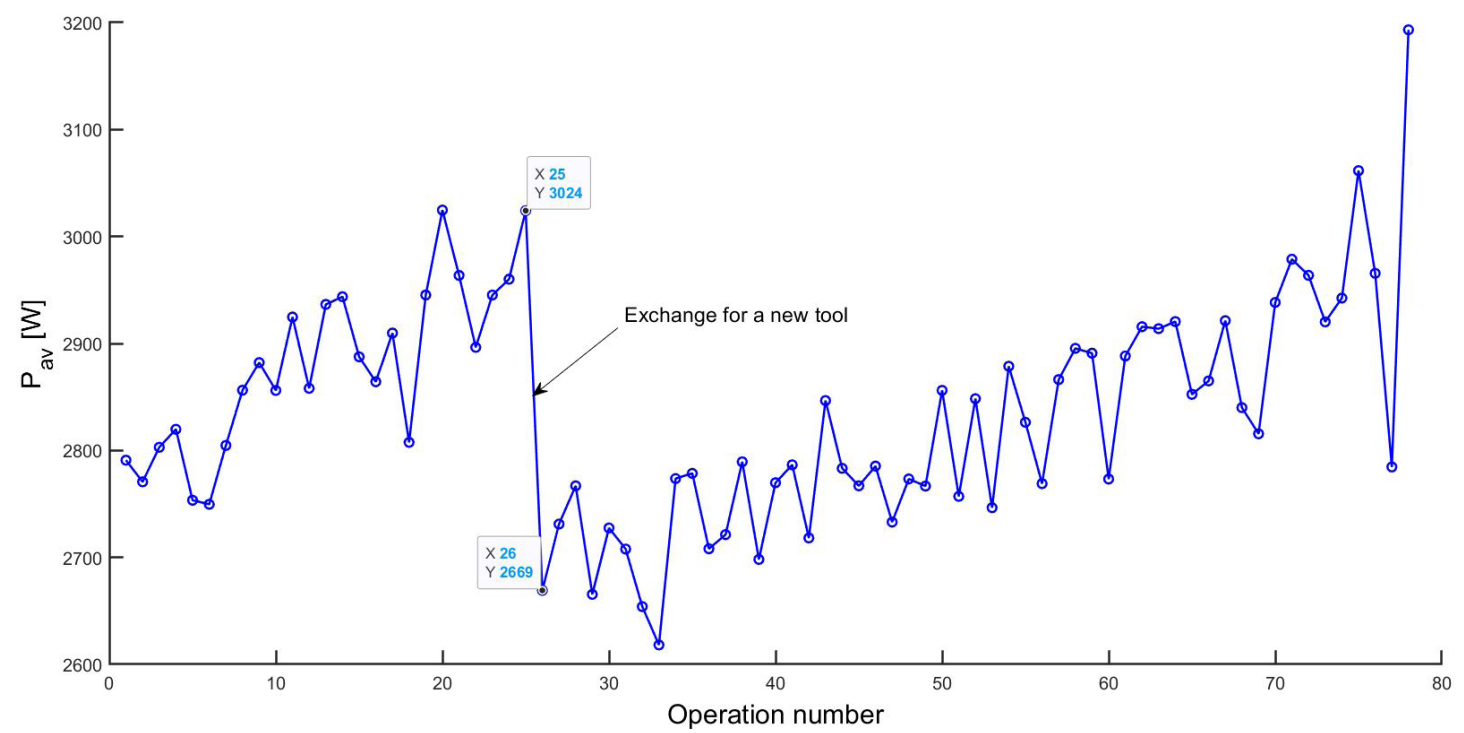

Fig. 6. Graph of average power consumption depending on the next machining cycle for the $\Phi 200$ bit R220.48-8200-09-12 from Seco Tools

this purpose. This is confirmed by the analysis of the average power consumed by the machine tool during various machining cycles implemented by the tool discussed in the examples above (Fig. 6).

Despite the fact that the total power consumption in subsequent operations does not always increase with the degree of tool wear, the upward trend is very clear (Fig. 6). Between the 25th and 26th cycle, the difference in average power was close to $400 \mathrm{~W}$, or approximately $15 \%$. The presented relationships were also observed in the operations carried out by other machining tools (Fig. 7).

\section{CONCLUSIONS}

The presented results show that the measurement of the average power during machining can be a criterion determining whether the tool is still useful for machining. The upward trend in the power consumption by the machine tool along with the progressive wear of the tool, observed for all cutting tools that were analysed in this study, allows the use of a mechanism consisting in informing the machine user about exceeding the average power level. In the case of mass production, setting the 


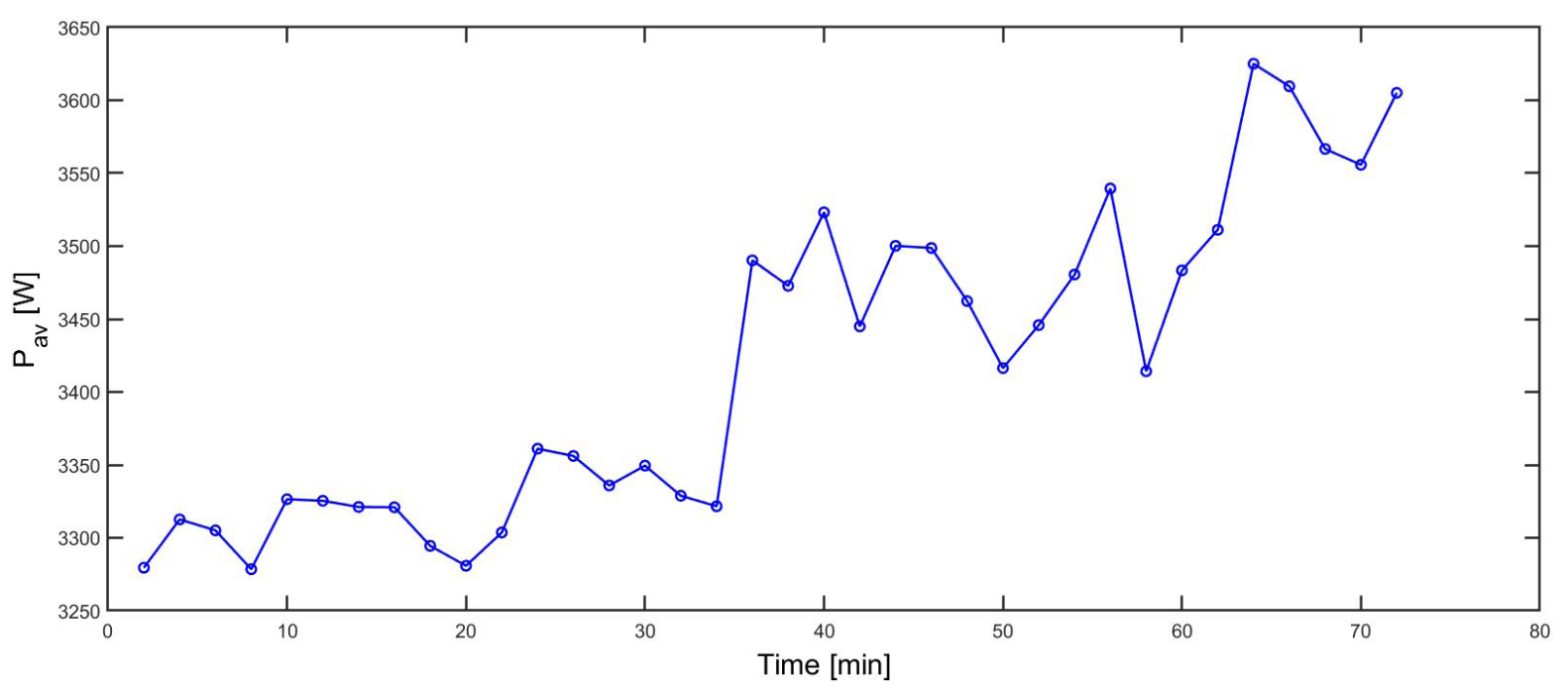

Fig. 7. Graph of average power for a single set of machining bits from the first to the last work cycle for the $\Phi 40$ bit R220.94-0040-08-6A from Seco Tools

average power threshold above which the machine tool informs the user about the need to change the tool is not complicated, and the knowledge about it can be used in the design of automatic machine energy monitoring systems [11].

The graphs presented indicate that the machine power consumption graphs during individual machining operations can also be useful in obtaining the information on the machining process. By analysing such a graph, the moments at which machining was carried out and when the machine was not performing such machining, can be identified. Instantaneous power consumption jumps by the machine tool may also indicate tool damage, which may cause the appearance of excessive errors in the dimensions and shape of the workpiece.

The on-going monitoring of the machine power consumption can also result in more economical tool management. The tool manufacturers' materials specify the time after which the cutting bits should be replaced and many companies follow these recommendations, although often such bits could still be in use in the machining process. A signal of exceeding the energy level would allow the tools to be used until the actual risk of catastrophic wear of the blade. The decision to replace the tool is usually based on several different signals, among which a signal of exceeding the energy level can play a key and decisive role.

The results obtained during the tests can be useful to create the algorithms aimed at forecasting the consumption of electricity during the machining operations of specific workpieces. At the moment, most of the algorithms offered by tool companies do not take into account tool wear, and those that do consider it, only determine the increase in the energy consumption with total tool wear. Determining how quickly the tool working time translates into an increase in electricity consumed by the machine tool will allow the improvement of the existing algorithms that predict the machine energy consumption.

\section{REFERENCES}

1. Chrzanowski J. Sonda narzędziowa $z$ funkcją pomiaru zużycia ostrza. Mechanik, 12, 2015, 14-17.

2. Chudy R., Grzesik W. Comparison of power and energy consumption for hard turning and burnishing operations of $41 \mathrm{Cr} 4$ steel. Journal of Machine Engineering, 4(15), 2015, 113-120.

3. Jemielniak K. Diagnostyka stanu narzędzi i procesu skrawania. Mechanik, 7, 2017, 504-510.

4. Kłosowski G., Rymarczyk T. Ocena stanu zużycia noża tokarskiego z zastosowaniem sztucznej sieci neuronowej. Innowacje w zarządzaniu i inżynierii produkcji, Tom II pod readakcją Ryszarda Knosali, Część XII Techniki informatyczne, metody symulacyjne w zarządzaniu przedsiębiorstwem i inżynierii produkcji, 2017.

5. Nosol A., Bartoszuk M., Winiarski P. Badania energochłonności procesu toczenia wstecznego CoroTurn PRIME. Zeszyty Naukowe Politechniki Rzeszowskiej 295, Mechanika 89, 2017, 361-367. 
6. Pieńkowski G., Krzyżanowski J., Mączka J. Problem oceny energochłonności wyrobów wytwarzanych metodami obróbki ubytkowej. Przegląd Mechaniczny, 11, 2005, 20-25.

7. PQM-701 power quality analyser. User's manual. 2014, 22.

8. Skoczyński W., Stembalski M., Roszkowski A., Jankowski T., Turek P., Piórkowski P. Sensory we współczesnych obrabiarkach sterowanych numerycznie. Mechanik, 11, 2016, 1740-1747.

9. Stembalski M. Sposoby ograniczenia zużycia energii przez obrabiarki skrawające do metali. Inż. Ap. Chem., 5, 2010, 107-108.

10. Terelak-Tymczyna A., Jardzioch A. Analiza wpływu planowania procesu produkcyjnego na wykorzystanie maszyn oraz efektywność energetyczną. Mechanik, 10, 2016, 1306-1307.
11. Vijayraghavan A., Dornfeld D. Automated energy monitoring of machine tools. CIRP-Annals Manufacturing Technology 59, 2010, 21-24.

12. Wittbrodt P. Nadzorowanie i prognozowanie stanu narzędzi skrawających $\mathrm{w}$ procesie skrawania. Innowacje w zarządzaniu i inżynierii produkcji, Tom I. Oficyna Wydawnicza Polskiego Towarzystwa Zarządzania Produkcją, Opole, Poland, 2014, 833-841.

13. Yontar A.A., Kartal Y. Investigation to effects of cutting parameter on tool wear tool life and machinability in machining operation. International Journal of Applied Science Engineering \& Management, 3(3), 2017, 13-21.

14. Żurawski, Ł., Storch, B., Zawada-Tomkiewicz A. Badania wpływu zużycia ostrzy w głowicy frezowej na chropowatość powierzchni obrobionej stopu tytanu. Zeszyty Naukowe Politechniki Rzeszowskiej 295, Mechanika 89, 2017, 393-400. 